\title{
The Domestic (Water) Buffalo in Africa: New and Unusual Records
}

\author{
R. Trevor Wilson
}

Bartridge Partners, Bartridge House, Umberleigh, Devon EX37 9AS, UK

\begin{abstract}
The domestic (water) buffalo is not indigenous to Africa. Some buffalo may have been taken to what is now Tunisia in Roman times about 2000 years ago. The species arrived in Egypt from Mesopotamia some 1200 years past and there were attempted introductions to the east coast of Africa by the Portuguese from India in the sixteenth century. The missionary-explorer David Livingstone took four buffalo from India to what is now southern Tanzania in 1866. In the twentieth century, European powers introduced buffalo to many of their African colonies. In addition to Egypt and Tunisia on the Mediterranean coast of north Africa buffalo have been introduced to fourteen subSaharan countries. Information on these introductions is sparse and is obviously incomplete. With the exceptions of Tanzania, where there have been buffalo for 90 years, and Mozambique, where there is documented presence over about 50 years, buffalo have been present for very short periods. They have disappeared without trace in some countries and have been culled in others due to adaptation or disease problems. Suitable ecological niches for buffalo exist in many African countries. Too few animals, failure to provide sufficient public financial resources and lack of private sector interest are among the reasons for the buffalo's failure to contribute to African livestock production.
\end{abstract}

Keywords: Introductions, exotic animals, domestic livestock, animal disease, adaptation.

\section{INTRODUCTION}

Little is known with regard to the domestic buffalo in Africa [1]. A standard work of reference on buffalo comprising more than nine hundred pages refers to Africa - with the exception of Egypt - only seven times and not all of these concern the domestic buffalo [2]. In a more recent text major attention is given to buffalo in 20 Latin American countries but only Egypt is given space for the African continent [3].

Buffalo were introduced to Egypt from India via Mesopotamia (present day Iran and Iraq) during the Arab invasion in the Ninth Century of the Christian Era (i.e. about 1200 years ago) [3]. Egypt is the exception in Africa in that the buffalo - usually referred to in the country by its Arabic name 'gamous' - is an integral component of the standard array of domestic livestock. In no other African country is the buffalo a species that contributes in any substantial way to food security and livelihoods.

Attempts to introduce buffalo - an exotic species in this context - to several African countries have been made in both the colonial period prior to about 1960 and to independent Africa since 1960. Two previous papers documented such attempts in nine countries, discussing successes (few) and failures (many) and commenting on the buffalo in Africa's future $[4,5]$. The current paper is complementary to the previous two and presents information from previously unpublished reports, from reports that have generally been

*Address correspondence to this author at the Bartridge Partners, Bartridge House, Umberleigh, Devon EX37 9AS, UK; Tel: +44 (0)1769 560244;

E-mail: trevorbart@aol.com overlooked and from other unusual reports and sources on the domestic (water) buffalo in seven countries on the African continent.

\section{BUFFALO IN AFRICA}

\section{Angola}

There is one report of about 4000 buffalo being imported to Angola from Brazil (Anonymous reviewer of this paper, personal communication, 23 April 2016). No further information has been found regarding these animals.

\section{Democratic Republic of Congo (Belgian Congo, Zaïre)}

Some 12 buffalo were imported to the Belgian Congo before 1914 [6], probably in 1910 [7]. There is evidence that two lots of buffalo, each of 20 head, were imported to the Congo in the 1930s from Ceylon (now Sri Lanka) and east Java [2]. These animals incurred heavy losses due to helminth parasites and suffered severely from attacks by blackfly (Family Simulidae, genus Onchocerca) [8]. An American stationed in The Congo during the Second World War claims to have hunted "water buffalo" on a plantation in August 1944 [9] but it seems probable that these were in fact the African buffalo Syncerus caffer. A further two males and ten females of the Kundi breed were imported from Pakistan in 1953 [6, 10-12]. Research on these animals showed the buffalo to be as susceptible to East Coast Fever as European cattle. In the same research series two attempts (in 1956 and in 1959) to cause piroplasmosis (Piroplasma bigemina) were unsuccessful although a local bullock died and 
anaplasmosis (Anaplasma marginale) could not be induced in buffalo although the species suffers from this disease elsewhere. The Congo buffalo were very susceptible to Trypanosoma vivax but less so to $T$. congolense and the appearance of symptoms was delayed in comparison to cattle [6, 10-13]. A male of this group was slaughtered in 1959 and found to be harbouring the fluke Paramphistomum explanatum, a parasite not otherwise reported from outside Asia and so the animal was presumably infected on arrival in the Congo. No information has been found on the ultimate fate of the buffalo in Congo but it seems likely that they disappeared as a result of the rinderpest epizootic of 1961. A recent reference claims buffalo were introduced to the lower Congo from Italy as a domestic animal [14] and cites Zeuner 1963 [15] as the source of the information: there is, however, no mention of this transfer in Zeuner [15].

\section{Eritrea}

One source states that a small number of water buffalo were taken to Eritrea (then an Italian colony) from Egypt in 1933 [14] but the statement is not substantiated and no other evidence of this movement has been found.

A total of 43 buffalo cows purchased from Italy in 2009 and introduced to Mendefera subzone are supposedly giving impetus to endeavours to boost dairy and meat output. Mr Zebib Kahsai, head of the Ministry of Agriculture's branch in the subzone, said that these buffalo cows were the first to be introduced to the country. It is claimed that the cows possess high resistance to disease and efforts are underway to reproduce them [16].

\section{Ethiopia}

It has been suggested that in view of the wide range of agroecological zones in the country introduction of the domestic buffalo would be feasible [17, 18]. There are, however, no records of the presence of domestic buffalo in Ethiopia and there has been no official followup to proposals that they should be introduced (Takele Taye Desta, Wolaita Sodo Agricultural College, personal communication, 8 March 2016)..

\section{Kenya}

Domestic buffalo were imported to what is now Kenya as early as the mid to late sixteenth century (1570-1595 AD). In 1594 the Portuguese commander at Fort Jesus (now in Mombasa on the Indian Ocean coast) to obtain buffalo for the garrison which should be superior to those formerly sent to Malindi (120 km north of Malindi also on the coast) [2] ${ }^{1}$. In 1610 these buffalo, from Belgaon (now Sri Lanka) needed to be doused three times per day with fresh, not salt, water. In 1631, Yusuf bin Hasan (who had converted to Christianity as a child and then reconverted to Islam) slaughtered all the garrison and all the buffalo and proclaimed himself Sultan of Mombasa. Having recovered control, in 1635 the new Captain-General of Mombasa ordered that further cattle and buffalo be brought to several Portuguese settlements on the coast from Jafnapatan (Sri Lanka). Under siege from Arab forces between 1696 and 1698 the Captain-General ordered that buffalo milk be reserved for women and children and in 1697 reinforcements from Goa (on the Indian mainland) arrived with 14 buffalo and diverse cattle but on 13 December 1698 two of the few remaining garrison blew themselves up, killing all the cattle and buffalo. Further cattle and buffalo were brought from Goa in 1728 but the garrison, with its cattle and buffalo, was driven out by Omani Arabs and thus ending the Portuguese period on that part of the Indian Ocean coast.

More recently, in the early 1990s a small group of swamp buffaloes was introduced to the Kenya coast at Tiwi by a retired French agriculturalist. The philanthropic aim was to repeat in Africa the revolution in arable agriculture to which buffalo draught power had contributed in Vietnam and other countries of Southeast Asia. Within a few months of arriving the owner had already become aware of the risks posed by trypanosomosis. By then one animal was recumbent and too weak to go out to graze and the remaining animals were restricted to grazing within one or two hundred metres of the seashore where bush clearing and the sea-breeze presumably reduced tsetse fly challenge. A few months later the sick animal had died and another had broken its neck after jumping from a small cliff in its effort to get into the sea and only one animal remained alive. A year later this animal too was absent and presumed dead along, sadly, with its visionary owner and importer (Paul Rossiter, personal communication, 24 April 2012).

\section{Madagascar}

A total of 52 buffalo were landed on Mozambique in February 1957. These animals were from New Delhi in

\footnotetext{
${ }^{1}$ The information on these early introductions is from Cockrill who obtained it from the reports of the captains-general of Mombasa and Malindi located in the Estoril archives in Lisbon via a personal communication of C A Walker in 1967.
} 
India, where they had been tested clear for several diseases, and were to be put in quarantine for two years. By November 1957, ten animals had died mostly from anaplasmosis. Weekly dipping failed to keep the animals free of ticks and by November 1957 ten animals had died, mostly from anaplasmosis although peracute heartwater accounted for some deaths; subsequently some animals were affected by tuberculosis and ascaris infection was frequent in young animals [19]. Following the two years' quarantine 22 animals were retained on Sainte-Marie Island and 20 were sent to the northeast coastal area of Tamatave. The herd was further split in 1964 and 1965.

The ultimate fate of the Madagascar buffalo is not known. There do not appear to be any buffalo in Madagascar in 2016 but it has not been possible to verify this as requests for information from the Animal Genetic Resources Section of the Ministry of Livestock Production have gone unanswered.

\section{Mauritius}

For several years the FAO Production Yearbook has given an estimate of 25 domestic buffalo on the island of Mauritius and it maintains this estimate for 2014 [20]. The breed data base of FAO DAD-IS [21] does not, however, include buffalo in species and breeds present. Buffalo were indeed imported from India in the 1960s by Indian immigrants and these were used by individuals and on sugar estates for milk and meat production and for draught power: it is not known what happened to these animals and there are no buffalo on Mauritius in 2016 (Micheline Pillay, Agricultural Research and Extension Unit, Livestock Department, personal communication, 10 March 2016).

\section{Mozambique}

It is possible that buffalo were introduced to the area that is now Mozambique during the seventeenth century when the Portuguese were expelled from Kenya but there is no firm evidence for this [2]. Another source [7] claims that some buffalo were imported to Mozambique after the conclusion of World War I (19141918) but no further trace of these animals has been found.

In recent times the first water buffalo, comprising 10 bulls and 90 cows, to arrive in Mozambique came from Italy by sea in 1960. They landed in Beira, were quarantined in Inhamízua $15 \mathrm{~km}$ from Beira and were later transferred to Zambézia. In 1973 this group had grown in numbers to 273 head [22].

Some Jaffarabadi $x$ Murrah buffalo were imported from the Naples region of Italy in 1969. These were distributed to various parts of the country. Numbers appear to have peaked at just less than 1000 head in 1996 and reached a low of less than 250 head in 2002 although numbers from different sources are conflicting [23-27]. An official report of 2004 stated that there were very significant numbers of River type buffalo in commercial livestock production systems in the low altitude agroecological regions of Sofala and Zambézia Provinces but that decreasing numbers relative to previous years could be due to low fertility and high mortality rates caused by inbreeding, abortions and diseases including heartwater and trypanosomosis. A breeding programme using semen imported from the original Naples area in Italy was being proposed to rectify some of these problems [27].

An absence of almost any type of management on government farms, leading in some cases to buffalo living effectively as feral animals was a major reason for the animals being ceded to the private sector. Later, however, some animals were taken back by the administration and in 2009 were kept at Mazimechopes research station (Figure 1), approximately $160 \mathrm{~km}$ north of Maputo (Antonio Rocha, former Senior Research Officer, Direcção Nacional de Pecuária, Ministério da Agricultura e Desenvolvimento Rural, personal communication, 10 March 2016).

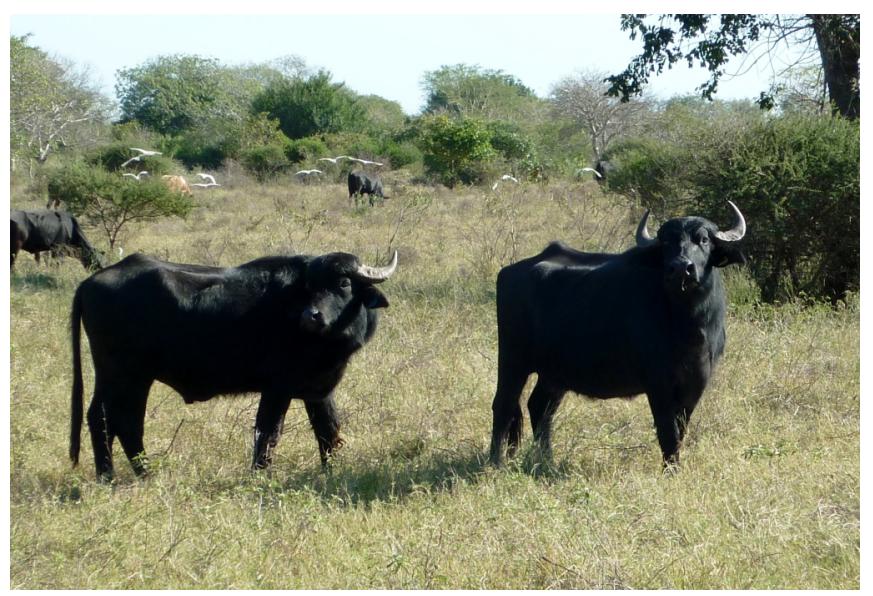

Figure 1: Domestic buffalo at Mazimechopes research station, Mozambique, in 2009 (Photo: Antonio Rocha).

\section{Republic of South Africa}

There is virtually no formal information on the domestic buffalo in South Africa. It seems, however, 
that domestic buffalo were imported about 1904 to the National Zoological Gardens in Pretoria and there were still buffalo there in 1966 when a single calf was born. There were also three male, four female and one female calf of domestic buffalo at Johannesburg zoo in 1966 and at that time there were Indian buffalo that had been acquired from zoos and circuses on at least three private ranches $[2]^{2}$. Attempts to hybridize African buffalo (Syncerus caffer) with domestic buffalo at the National Zoological Gardens in Pretoria during the 1930s were unsuccessful [28]. The FAO data base has listed Murrah buffalo as present in South Africa for many years and continues to list it for the year 2016 [21], the information supposedly being supplied by the Farm Animal Genetic Resources Unit in the Department of Agriculture. In an earlier exchange of correspondence, however, the Unit claimed to have no knowledge of any domestic buffalo and went on to state that in the republic buffalo were regarded as wild animals (Tlou Caswell Chokoe, Deputy Director, Farm Animal Genetic Resources, Ministry of Agriculture, personal communication, 9 December 2011).

The last of three old domestic buffalo at Johannesburg zoo died in 2015. A bull was purchased from a nearby farm to restart the herd and was in quarantine in early March 2016: two cows were also purchased and were awaiting transfer to the zoo (Piet Malepa, Manager, Animal Welfare and Management, Johannesburg City Parks, personal communication, 3 March 2016). It has not been possible to establish the current status of buffalo at the National Zoological Gardens in Pretoria.

One herd of domestic buffalo in Western Cape produces mozzarella cheese (Figure 2). The establishment, origin and import of the animals and history of this herd is not clear as there are two extant versions: ${ }^{3}$

Mediterranean Water Buffalo are raised on Buffalo Ridge farm in Wellington, Western Cape, to provide the milk to make authentic buffalo mozzarella. Wayne and Michelle Rademeyer are the farmers behind this venture, and base their farming methods on biodynamic principles. Almost five years ago, 21 cows

${ }^{2}$ Cockrill obtained this information on buffalo in the 1960s through personal information supplied by various local correspondents.

${ }^{3}$ Multiple requests to several authenticated e-mail addresses for Buffalo Ridge have remained unanswered. and three bulls (Valentino, Don Juan and Casanova) arrived at Cape Town International Airport. Wayne had spent months searching across the globe for the right animals - healthy, prime specimens that he finally found on a farm in Australia. A year and a half later, he sold his first buffalo mozzarella cheese - one of a kind in South Africa. "This is how my dream became a reality", he says. The herd is now 80-strong [29].

and

Buffalo Ridge is a farm just outside Wellington in the Western Cape. We have almost 30 Water Buffalo, imported from Campana in Italy in 2008. Owned by Wayne and Michelle Rademeyer, the farm has been in operation since 2009, with the very first batch of Buffalo Ridge Mozzarella sold in February 2010. We also make delicious Buffalo Yoghurt, which we sell in smaller quantities to selected delis and small markets in and around Cape Town [30].

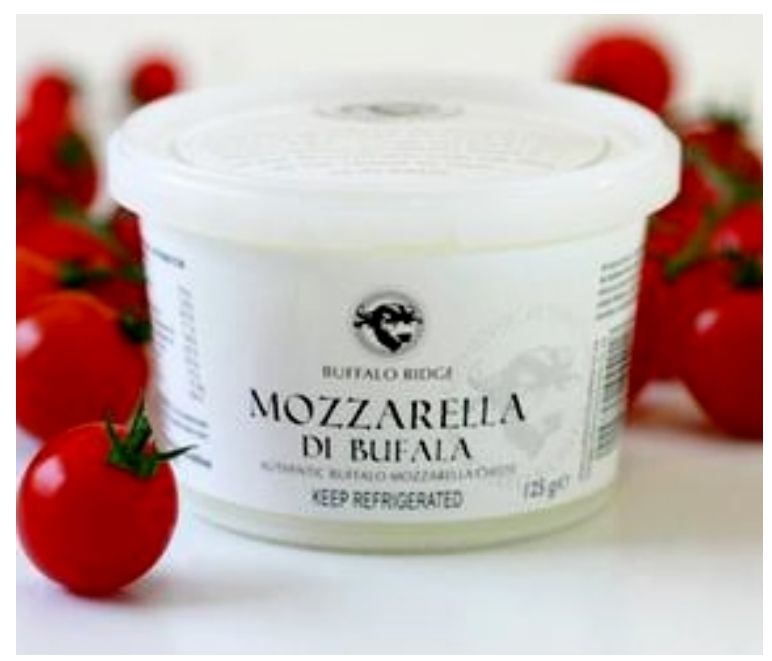

Figure 2: Packaged Mozzarella di Bufala from Buffalo Ridge Farm, Western Cape, South Africa (Source: http://buffaloridge.withtank.com/about-us/).

A shipment of buffalo from the State of Victoria to South Africa was made in mid 2006 [31].

\section{Tanzania}

The overall history of water buffalo in the colonial and post-colonial periods is well documented and has been summarized elsewhere [4, 5]. Buffalo were 
imported to the then Tanganyika Territory from Zanzibar in 1926 and have been present in the country ever since. Tanzania is the only country in Africa south of the Sahara with such a long history of buffalo experimentation and production and is apparently the only one with an official policy regarding production and development of the domestic buffalo [32]. Throughout its 90 -year history in the country it has always been at risk and suffered from trypanosomosis and East Coast Fever and other tick-borne diseases if not adequately protected against these diseases.

One little known record of domestic buffalo in Tanzania is its attempted introduction by the missionary-explorer David Livingstone in 1866 [33]. Livingstone was anxious to test the ability of the buffalo

\section{Table 1: Narrative of Events Pertaining to Livingstone's Buffalo in Southern Tanzania: March-July 1866}

\begin{tabular}{|c|c|}
\hline 27 March & Making camels' saddles, and repairing those of the mules and buffaloes \\
\hline 7 April & Evening: buffaloes and camels first bitten by tsetse fly \\
\hline 17 April & $\begin{array}{l}\text { The Havildar assured Livingstone two buffaloes were sufficient to carry the necessary baggage but he found they had more than } \\
\text { full loads for two each of buffaloes, mules and donkeys; when they fell down under them he was assured with much } \\
\text { positiveness they were not overloaded and he had to remain silent or express the opinion that all the animals would be killed }\end{array}$ \\
\hline 20 April & Tsetse again biting buffaloes \\
\hline 1 May & $\begin{array}{l}\text { Buffaloes again bitten by tsetse and by another fly exactly like the house-fly but having a straight hard proboscis instead of a } \\
\text { soft one; other large flies make the blood run: tsetse do not disturb the buffaloes but these others and the smaller flies do }{ }^{a}\end{array}$ \\
\hline 2 May & Buffaloes again bitten by tsetse \\
\hline 4 May & $\begin{array}{l}\text { Buffaloes again bitten by tsetse and other flies (which look much more formidable than tsetse) and blood of arterial colour } \\
\text { flowed down, a symptom not previously seen by Livingstone: grey buffalo sick but attributed to unmerciful loading }\end{array}$ \\
\hline 7 May & $\begin{array}{c}\text { Grey buffalo in convulsions: the cruelty of these sepoys vitiates experiment and Livingstone expects many camels, one buffalo } \\
\text { and one mule to die }\end{array}$ \\
\hline 8 May & $\begin{array}{l}\text { One mule very ill; one buffalo drowsy and exhausted; one camel a mere skeleton from bad sores; and another has an enormous } \\
\text { hole at the point of the pelvis, which sticks out at the side: suspect that this was made maliciously }\end{array}$ \\
\hline 2 July & $\begin{array}{l}\text { Successive crowds of people come to gaze and appearance and acts often cause a burst of laughter; poodle dog, buffalo-calf } \\
\text { and only remaining donkey greeted with same amount of curiosity and laughter-exciting comment as myself }\end{array}$ \\
\hline 15 July & $\begin{array}{l}\text { Town of Matak: retaining their brutal feelings the sepoys killed the donkey by striking it on the head when in boggy places into } \\
\text { which they had driven it loaded; the Havildar killed the young buffalo and ate it, having hatched what he thought a plausible } \\
\text { story - it had died and tigers had devoured it - "Did you see the stripes of the tiger?" said I and all declared they saw them } \\
\text { distinctly. This gave us an idea of their truthfulness as there is no striped tiger in all Africa }\end{array}$ \\
\hline
\end{tabular}

Note: ${ }^{a}$ The small fly is the stable fly Stomoxys calcitrans; the larger ones are horse flies of the Family Tabanidae.

${ }^{\mathrm{b}}$ It is possible that the striped hyaena Hyaena hyaena made a nuisance of itself around camp as this species did when the Author was trekking cattle in this part of southern Tanzania in 1965

Source: [33], modified by the Author. 


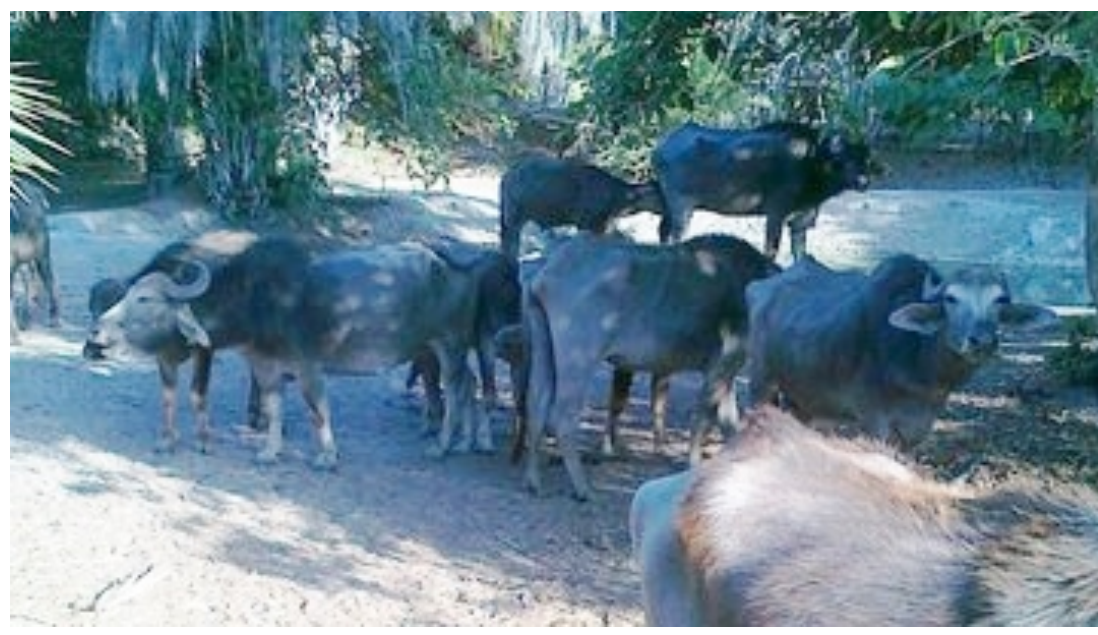

Figure 3: A group of buffalo at Dar es Salaam zoo, Tanzania (Source: Trip Advisor; " src="https://mediacdn.tripadvisor.com/media/photo-s/03/b8/4b/00/dar-es-salaam-zoo.jpg"/></a><br/>).

(and of camels and donkeys) to survive and work in areas infested by tsetse flies ${ }^{4}$. He arrived at Zanzibar in early March with three adult buffalo and one calf (and six camels, two mules and four donkeys) and shortly afterwards sailed with his animals in a dhow to what is now southern Tanzania. Unloading his animals was the first of multiple problems relating to their behaviour, their health and food and the intransigence of his porters (Table 1). A combination of disease, probable poor nutrition and cruelty by Livingstone's entourage saw all his animals dead within three months of arriving in the country.

In September 2013 there were 19 buffalo at the Dar es Salaam zoo (Figure 3), these having been obtained from government research stations (personal observation).

The FAO database [21] gives a population of 14002000 buffalo in Tanzania in 2013, this information being considered reliable as it is based on survey at species level: the number shows a decreasing numerical trend compared to an estimate of more than 7900 head in 2001.

\section{Tunisia}

Buffalo may have been introduced to Tunisia in Roman times [36]. Further animals were presented by

\footnotetext{
${ }^{4}$ Livingstone was the first to suggest the relationship between trypanosomes (the parasite) and tsetse flies (the vector) when, in 1852 on an earlier voyage, he noted the occurrence of a disease along the Limpopo and Zambezi rivers and the shores of Lakes Nyasa and Tanganyika from which all his cattle died after being bitten by tsetse flies (recorded in Vickerman, 1997 [34]). It was not until some 30 years later, however, that the Scottish pathologist and microbiologist David Bruce identified trypanosomes as the causative agents of the disease in animals and of sleeping sickness in humans [35].
}

the King of the Two Sicilies to Ahmed Bey of Tunisia in 1840. By 1882 the population was estimated to be 1000 animals but this was reduced by hunting in the following years. Epstein [7] quotes Boettger [37] in stating that there were further imports of buffalo to be used for "agricultural purposes". The statement of Epstein [7] in 1971 that all buffalo had been exterminated was not correct although all except three buffalo had been shot in the late 1950s and early 1960s. After this, conservation measures were put in place and there is now a free-ranging herd of about 60 animals at Lake Ichkeul National Park, near Bizerta in northern Tunisia [38]. Testament to the buffalo as a national asset is evident from a sculpture of the animal at the entrance to the National Park (Figure 4) and to the issue of a postage stamp bearing its image (Figure 5).

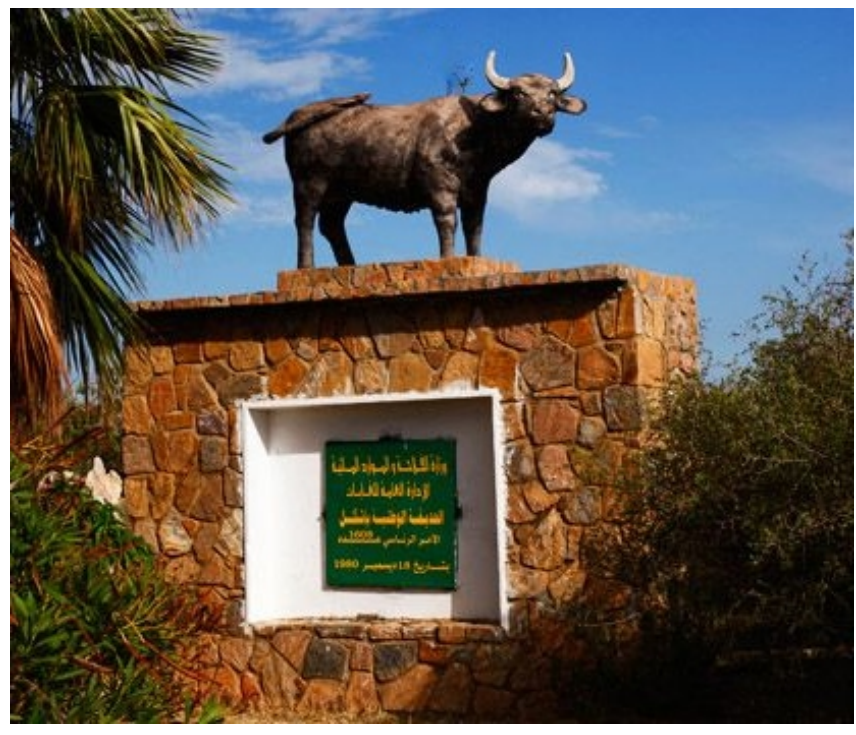

Figure 4: Buffalo sculpture at the entrance to Lake Ichkeul National Park, Tunisia (Photo: Naim ben Saad). 


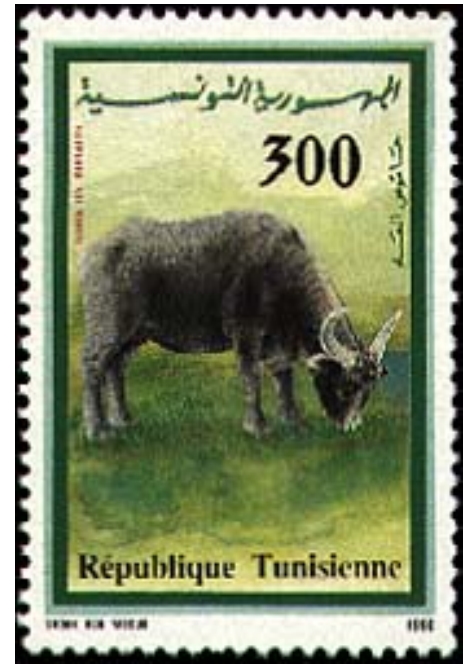

Figure 5: Postage stamp illustrating domestic buffalo, Tunisia.

\section{Uganda}

The information on buffalo in Uganda provided by Vietmeyer, 1981 [1] and reported in Wilson, 2012 [5] differs from that given in Cockrill, 1974 [2] $]^{5}$. A main difference is that Vietmeyer [1] indicates that a group of 1 bull and 12 cows was imported in 1969 but Cockrill [2] reports that 2 male and 8 in-calf females, being a present to Uganda from an Indian State Farm, were imported in 1971. The "Vietmeyer herd" was kept at Entebbe for seven years where it grew to 2 bulls and 40 cows with other males being slaughtered: the "Cockrill herd" was sent to Lusanke in Bugerere County in East Mango District and in November 1972 there were 18 animals. According to Vietmeyer [1] buffalo were unaffected by cattle diseases endemic to the area, were resistant to the major tick-borne diseases and were unaffected by virulent strains of East Coast Fever (theileriosis) which killed large proportions of cattle that were not provided with an intensive regime of protective acaricidal dipping [1]. According to Cockrill [2]several animals died of suspected East Coast Fever in spite of being dipped once every week and two animals died of experimentally induced Trypanosoma infection.

In a report to FAO on the status of the country's livestock resources the Uganda National Animal Genetic Resources Centre and Data Bank [39] stated that buffalo were first brought to Uganda in the 1960s.

\footnotetext{
${ }^{5}$ Vietmeyer states his information was provided by G L Corry, Director, Veterinary Research Services, Entebbe whereas Cockrill obtained his information from E P S Rogers, Chief Veterinary Research Officer Uganda. Information by the latter was provided in 1972 which was presumably some years earlier than that supplied by the former.
}

In 1992 there was a total of only 10 buffalo in the country but in February 2004 the number of buffalo was unknown [39].

\section{DISCUSSION}

The domestic (water) buffalo is not native to Africa. As an animal to contributing to food security and livelihoods it is found only in Egypt where it has been present for many hundreds of years $[3,40]$. An earlier paper on domestic buffalo in Africa [5] reported introductions or attempted introductions to nine countries south of the Sahara: this paper adds records from one north African country and five subSaharan countries or countries in the Indian Ocean that are members of the African Union. In total, therefore, it is known that 16 countries have attempted to introduce the domestic buffalo (Figure 6 ). In all of these countries (and in many others in Africa) there are physical and biological environments suitable to the buffalo.

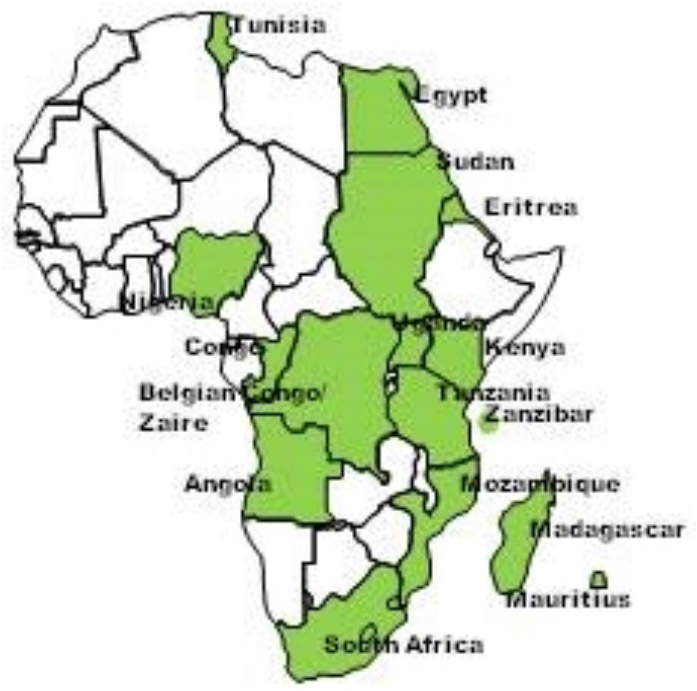

Figure 6: Map of African countries to which domestic buffalo have been introduced (Source: compiled by the author).

It is considered by many that buffalo have considerable advantages over the present array of domestic livestock in Africa in terms of their meat (tasty, lean, low saturated fat), milk (18-23 per cent total solids compared to $13-16$ per cent in cow milk) and in draught and transport performance. Supposedly efficient converters of low quality feed buffalo make good use of less digestible feeds (rice straw, maize stover, sugarcane wastes) and they are easy to maintain on locally available roughages and crop residues.

Most African countries already have a broad array of domestic livestock species. Most of these are said to 
be of poor genetic potential and of low productivity but the three main ruminant species (cattle goats and sheep) already provide both meat and milk and cattle are extensively used for draught purposes. African indigenous livestock may be in need of "enhancement" [41] but it is not clear how the introduction of very small numbers of exotic species will enhance the productivity of native livestock types that are already well adapted to their local environments.

With the qualified exceptions of Tanzania and Mozambique - and of course Egypt - introductions of buffalo to African countries have usually very quickly failed in spite of often favourable physical and biological environments. Among the obvious reasons for failure are low numbers of animals and a failure to bring in new genetic material resulting in reduced performance from inbreeding, a lack of clear objectives and output goals and a failure to move animals into local production systems away from an experimental environment. Disease has also been a constraint in most countries as buffalo have encountered pathogens not met in their Asian environments: these include trypanosomosis [2, 13, 27, 33] and East Coast Fever $[2,4,12]$ as well as many tick-borne diseases. In Nigeria an outbreak of streptothricosis on the ranch that was home to the buffalo during their short sojourn in the country resulted in their all being slaughtered in 1979 [2].

Africa is home to vast numbers of cattle, goats and sheep. These are, and will continue to be, the continent's main producers of meat, milk and of renewable energy for farm and transport operations. Their needs and their peculiarities are well understood by African people. Introducing additional exotic species can be considered in some respects as an attempt to reduce risk and broaden the production base. The African experience so far has not been successful in contributing to food security as a whole or improved livelihoods for livestock producers. There does not seem to be any comparative advantage in governments disbursing considerable amounts of financial and human resources in promoting buffalo and indeed they have not done so. The social and political environments, unlike the physical and biological ones, are therefore additional major constraints to buffalo production in Africa. Better use of the limited and limiting financial and human resources to improve livestock production and productivity would yield more worthwhile results if expended on the known rather than the unknown. In Africa in general, exotic animals can best be seen as a diversion to mainstream production rather than as a diversification of it. They are, almost without exception, not the right animal in the right place and are not fit for purpose [42].

\section{ACKNOWLEDGEMENTS}

I am extremely grateful to those people mentioned by name in the text who responded to my requests for information. I also thank two anonymous referees for comments on an earlier version of this paper.

\section{REFERENCES}

[1] Vietmeyer $N$. The water buffalo: new prospects for an underutilized animal. Washington DC: National Academy Press 1981

[2] Cockrill WR. The husbandry and health of the domestic buffalo. Rome: Food and Agriculture Organization 1974.

[3] Bhatt PN. Buffaloes In: Payne WJA, Wilson RT, authors. An introduction to animal husbandry in the tropics. 5 ed. Oxford: Blackwell Science 1999; 325-404.

[4] Wilson RT. The domestic (water) buffalo in mainland Tanzania. Trop Anim Hlth Prod 2008; 40: 567-70. http://dx.doi.org/10.1007/s11250-008-9135-4

[5] Wilson RT. The past and present of and potential for the domestic (water) buffalo in Africa. Trop Anim HIth Prod 2012; 44: 1367-73.

http://dx.doi.org/10.1007/s11250-012-0097-1

[6] Mammerickx M. Les buffles d'Asie importés au Congo. Observations faites après sept années de multiplication. Publication Série Technique No 64. Bruxelles: Institut national pour l'étude agronomique du Congo 1961.

[7] Epstein $\mathrm{H}$. The origin of the domestic animals of Africa (2 volumes). New York: Africana Publishing Corporation 1971.

[8] Bequaert JC. The black flies, or simulidae, of the Belgian Congo. Am J Trop Med Hyg 1938; 6(Suppl): S1-19 (116136).

[9] Laxait R. A private war: An American code officer in the Belgian Congo. Reno: University of Nevada Press 1998.

[10] Gillain J. Importation de bétail pakistanais au Congo belge. Bulletin d'Information de l'Institut National pour l'Etude Agronomique du Congo Belge 1953; 2: 139-82.

[11] Gillain J. Introduction au Congo belge du buffle d'eau originaire du Pakistan. Bulletin d'Information de I'Institut National pour l'Etude Agronomique du Congo Belge 1955; 4: 27-34.

[12] Mammerickx M. Le buffle (monographie du genre Bubalus). Bulletin Agricole du Congo Belge 1960; 51: 171-211.

[13] Lambelin G, Ectors F, van Vaerenbergh B, Mammerickx M. Sensibilité du buffle de l'Asie aux principales maladies à protozoaires du bétail au Congo belge. Essais expérimentaux et observations cliniques. Annales de la Societé Belge de Médecine Tropicale 1960; 40: 189-97.

[14] Long JL. Introduced mammals of the world: Their history, distribution and influence. Wallingford, UK: CABI Publishing 2003.

[15] Zeuner FE. A history of domesticated animals. London: Hutchinson 1963.

[16] Eritrea: Efforts to boost milk and meat products bearing encouraging outcome in Mendefera sub-zone. Asmara: Government of Eritrea. 16 September 2009 http://reliefweb.int/report/eritrea/eritrea-efforts-boost-milkand-meat-products-bearing-encouraging-outcomemendefera [cited 2016 March 7]. 
[17] Takele Taye Desta. Introduction of domestic buffalo (Bubalus bubalis) into Ethiopia would be feasible. Renewable Agriculture and Food Systems 2012; 27: 305-13. http://dx.doi.org/10.1017/S1742170511000366

[18] Taye T, Ayalew W. Would introducing domestic buffalo into Ethiopia be worthwhile? In: The role of agricultural universities/colleges in transforming animal agriculture in education, research and development in Ethiopia: Challenges and opportunities. Proceedings of the 13th Conference of the Ethiopian Society Animal Production 2005: August 25-27; Addis Ababa 2006; pp. 85-92.

[19] Buck G. Opération buffle, Madagascar. Maisons-Alfort: Institut d'élevage et de médecine vétérinaire des pays tropicaux 1965.

[20] FAO. Statistical Yearbook 2014. Food and Agriculture Organization: Rome. file:///C:/Users/Trevor/AppData/Local/ Temp/095ebd27-65b8-43eb-b16f-068261037f43.xls.htm [cited 2016 March 6].

[21] DADIS. Domestic animal diversity information system: breed database for Mauritius. Rome: Food and Agriculture Organization. dad.fao.org. [cited 2016 March 5 and 2016 March 12].

[22] de Pinho Morgado F. A pecuária no centro de Moçambique: As provínvias do centro Zambézia, Tete, Manica e Sofala. Lisbon: Assírio Bacelar 2004; 104-5.

[23] Macie S, Muir J. The water buffalo experience in Mozambique. In: Proceedings of the Third All Africa Conference on Animal Agriculture 1996: April 1-4; Pretoria, South Africa 1996.

[24] DINAP. Relatório anual de 2002. Maputo, Mozambique: Direcção Nacional de Pecuária, Ministério da Agricultura e Desenvolvimento Rural 2003.

[25] MADAL. Sumário da evolução da manada de búfalos na Zambézia. Zambézia, Mozambique 2003. Unpublished.

[26] Maciel S, Harun M, Capece B. The status of farm animal genetic resources in Mozambique. First National Country Report. Maputo, Mozambique: MADER; DAD-IS; Food and Agriculture Organization of the UN: Rome; 2004. http://ftp.fao.org/docrep/fao/011/a1250f/annexes/CountryRep orts/Mozambique.pdf [cited 2016: March 13].

[27] Maciel S. The use of biotechnology in conservation of indigenous animal genetic resources in Mozambique. In: Rege JEO, Nyamu AM, Sendalo D, Eds. The role of biotechnology in animal agriculture to address poverty in Africa: Opportunities and challenges (Proceedings of the 4th All Africa Conference on Animal Agriculture and the 31st Annual Meeting of the Tanzania Society for Animal
Production (TSAP), 2005; September 20-24; Arusha, Tanzania. pp. 299-308.

[28] Bigalke RC, Neitz O. Indigenous ungulates as a possible source of new domesticated animals. J S Afr Vet Med Assoc 1954; 25(4): 45-54.

[29] Food with a Story. Buffalo Ridge. 2016. http://www.foodwithastory.co.za/ View-Business/240/BuffaloRidge [cited 2016; March 3].

[30] Buffalo Ridge. Buffalo Ridge. 2016. http://buffaloridge. withtank.com/about-us/ [cited 2016; March 3].

[31] ABIC. Buffalo News 6(4): 1-4. Tamban, NSW, Australia 2411: Australian Buffalo Industry Council; 2006. Also available at http://buffaloaustralia.org.

[32] URT. National Livestock Policy. Dar es Salaam, Tanzania: Ministry of Livestock Development 2006.

[33] Waller $\mathrm{H}$. The last journals of David Livingstone, in Central Africa, from 1865 to his death. Continued by a narrative of his last moments and sufferings, obtained from his faithful servants Chuma and Dusi, in Two Volumes. - Vol. I [18661868]. London: John Murray 1874).

[34] Vickerman K. Landmarks in trypanosome research. In: Hide G, Mottram JC, Coombs GH, Holmes PH, Eds., Trypanosomiasis and leishmaniasis: biology and control. Wallingford, UK: CAB International 1997; pp. 1-38.

[35] Bruce D. Preliminary report on the tsetse fly disease or nagana in Zululand. Bennett and Davis: Durban 1895.

[36] Lever C. Naturalized mammals of the world. New Jersey: Prentice Hall Press 1985

[37] Boettger CR Die Haustiere Afikas. Jena: Veb Gustav Fischer Verlag: Jena; 1958.

[38] PNI. Parc National d'Ichkeul. http://ichkeul.e-monsite.com/; 2016 [cited 2016: March 4].

[39] NAGRCDB. Uganda contribution to the report on The State of the World's Animal Genetic Resources. Kampala: National Animal Genetic Resources Centre and Data Bank; 2004. $\mathrm{ftp} / / / \mathrm{ftp}$. fao.org/docrep/fao/011/a1250f/annexes/CountryRepo rts/Uganda.pdf [cited 2016: March 7 2016].

[40] Shalash MR. The water buffalo of Egypt. Acta Vet Scand Suppl 1988; 83: 66-79.

[41] Pelant RK, Gudala DJ, Chandra B, Kinney E. Camels for socioeconomic development in India and Tanzania. J Came Prac Res 1997; 6: 119-22.

[42] Wilson RT. Fit for purpose - the right animal in the right place. Trop Anim HIth Prod 2009; 41: 1081-90. http://dx.doi.org/10.1007/s11250-008-9274-7

\section{DOI: http://dx.doi.org/10.6000/1927-520X.2016.05.02.1}

(C) 2016 R. Trevor Wilson; Licensee Lifescience Global.

This is an open access article licensed under the terms of the Creative Commons Attribution Non-Commercial License (http://creativecommons.org/licenses/by-nc/3.0/) which permits unrestricted, non-commercial use, distribution and reproduction in any medium, provided the work is properly cited. 